\title{
Drivers of buyer retention in e-commerce: The role of transaction characteristics and trust
}

\author{
Karina Anatasia Asmara Silitonga ${ }^{\mathrm{a}}$, A. Fakhrorazi ${ }^{\mathrm{b}}$ and Ridho Bramulya Ikhsan ${ }^{\mathrm{c}^{*}}$
}

${ }^{a}$ Economy Faculty, Prima Indonesia University, Medan, Indonesia

${ }^{b}$ Ghazali Shafie Graduate School of Government (GSGSG), COLGIS, Universiti Utara Malaysia, Malaysia

${ }^{c}$ Management Department, BINUS Online Learning, Bina Nusantara University, Jakarta, Indonesia 11460

\section{H R O N I C L E}

\begin{tabular}{l}
\hline Article history: \\
Received: May 30, 2020 \\
Received in revised format: \\
May 302020 \\
Accepted: June 30, 2020 \\
Available online: \\
June 30, 2020 \\
\hline Keywords: \\
Customization \\
Contact interactivity \\
Care \\
Character \\
Trust \\
Retention and e-commerce \\
\hline
\end{tabular}

\section{A B S T R A C T}

E-sellers need to build buyer confidence in new transactions through a variety of transaction services so they can create retention behavior drivers. The research aim is to examine the driving factors for shaping customer retention by understanding the pattern of transaction characteristics and trust in online purchases in e-commerce. Questionnaire data collection came from buyers in the top six e-commerce in Indonesia with a purposive technique. We use PLS-based SEM analysis to answer hypotheses. As a result, we accepted all hypotheses, namely customization, contact interactivity, care, and character factors that had positive and significant effects on trust and buyer retention. Trust has proven to be an essential factor in shaping buyer retention on e-commerce sites.

CO 2020 by the authors; licensee Growing Science, Canada

\section{Introduction}

In the digital era, the demand internet seems to have turned into a primary need for society. They are starting from ordering activities for online transportation, food, entertainment, and purchasing online. Computer technology and communication flows have redesigned trading methods, removed time limits, and places. They have shaped cybernetic societies, so they become new demands for producers in creating products and services (Maxwell \& Khan, 2018). In online business, e-sellers need to reach a diversity of buyers so that e-marketing activities must target a unique market. It includes product development besides procedures and processes that reflect the buyer's wishes (Alharbi \& Alhider, 2018). Jain Nikunj (2017) conducted an in-depth literature review and has suggested that availability, timeliness, conditions, ease of return, e-business quality, product quality, and price, are related to shopping satisfaction and customer repurchase intentions in e-tailing. From the seller's perspective, we have recognized buyer loyalty as the primary path to profitability. The high cost of acquiring new buyers makes the relationship unprofitable during the initial transaction (Reichheld \& Sasser, 1990). E-sellers will benefit when buyers make repeat purchases, reducing costs to serve buyers. This understanding can help e-sellers gain competitive advantage by devising strategies to increase buyer retention. We have recognized repurchase behavior as an essential behavior and is a benchmark for sellers of buyer retention (Bloemer, de Ruyter, \& Wetzels, 1999; Oliver, 1999; Otim \& Grover, 2006). We focus this research on behavioral factors because they have direct benefit implications for e-sellers. Broadly, buyer trust has been studied by researchers in marketing management and information systems (SI). They learn about online trading on a web or mobile basis (Doan, 2020; GrabnerKraeuter, 2002; Jumin Lee, Park, \& Han, 2011; Li \& Yeh, 2010; Lin, Wang, Wang, \& Lu, 2014; Salimon et al., 2018; Sarkar, Chauhan, \& Khare, 2020). Trust plays a vital role in interpersonal relationships, organizational behavior, and business transactions (Dirks \& Ferrin, 2001; Williamson, 1993; Zaheer, McEvily, \& Perrone, 1998). In online transactions, trust is the key to 
supporting buyers willing to make repeat purchases, so it is necessary to study patterns of individual transaction characteristics to encourage buyers to make repeat purchases. (Jaiswal, Niraj, Park, \& Agarwal, 2018). Online buyers show a low level of trust in online-based merchants (Culnan \& Armstrong, 1999), so it becomes a significant reason many buyers choose not to shop online (Hoffman, Novak, \& Peralta, 1999).

Based on the prior explanation, this study explicitly discusses the driving factors for shaping buyer retention behavior by understanding models of transaction characteristics and trust in online purchases on e-commerce sites.

\section{Literature Review}

\subsection{Transaction Characteristics on Trust and Retention}

This research discusses the transaction characteristics in e-commerce to form buyer retention by referring to the $8 \mathrm{C}$ concept developed by Srinivasan, Anderson, and Ponnavolu (2002), namely customization, contact interactivity, care, character, cultivation, community, choice, and convenience. However, we only study four dimensions, namely customization, contact interactivity, care, and character, because the results of our first survey, four other dimensions did not meet the validity and reliability requirements. Customization is the capability of e-sellers in tailoring goods, service, and transaction environment to the buyer individually (Srinivasan et al., 2002). Customization is also one of the strategies adopted by e-sellers to serve better buyers (Jihyun Lee, Lee, \& Lee, 2012). Online interactions and the distribution of real-time data in e-commerce environments have helped e-sellers understand buyer needs more quickly (Coupey, 2001) and adjust products and services according to buyer expectations (Zo, 2003). With the support of internet technology, it is clear that e-sellers can offer new opportunities to adjust offers to buyers (Coelho Pedro \& Henseler, 2012), opening up opportunities to build buyer confidence. In the context of e-commerce, we conclude that the more e-sellers can customize products and services, the more they make buyers believe in e-sellers and ultimately shape their behavior for retention. Contact interactivity leads to the fluid nature of the commitment of e-sellers and their buyers into their website (Srinivasan et al., 2002). Some researchers have reviewed the effect of interactivity on buyer loyalty in electronic commerce (Deighton \& Sorrell, 1996; Watson, Akselsen, \& Pitt, 1998). Interactivity has the potential and essential influence in building relationships in an online context (Berthon, Pitt, \& Watson, 1996; Cuneo, 1995; Ha \& James, 1998). In practice, contact interactivity as the availability and effectiveness of buyer support tools on e-commerce sites, and how e-retailers facilitate two-way communication with buyers (Srinivasan et al., 2002). Alba et al. (1997) explain that interactivity facilitates the process of finding products and services quickly and precisely as desired, making it easier for buyers who have a dependency on memory. We conclude that with the interactivity of contacts in e-commerce sites, e-sellers get extensive benefits to shape buyers' satisfaction and retention behavior.

The concern is translating as e-seller's attention to buyers in the phase before and after the transaction. The aim is to build trust and long-term relationships with buyers (Srinivasan et al., 2002). For example, making a promise that there is no disruption during the transaction process and providing guarantees if the goods received are not following the order. Srinivasan et al. (2002) interpret that buyers are presented with information about the availability of product choices and order status and efforts to minimize disruption in the transaction process. E-commerce sites can develop automatically if buyers often make repeated transactions (Mohapatra, 2013) and provide personalized product offerings with customer service. Failure to provide services has become a negative signal for business in the future (Bolton \& Drew, 1992). Several studies prove disruption in service negatively influences buyers to repurchase (Bitner, Booms, \& Tetreault, 1990; Boulding, Kalra, Staelin, \& Zeithaml, 1993; Das, Mishra, \& Cyr, 2019; Nili, Barros, Johnstone, \& Tate, 2019; Susanti, Prijono, Rizal Edy, \& Asnan, 2019; Hoque, 2018). Therefore, every e-seller must maximize buyer service in order to create trust and build more intensive retention behavior.

Character is defined as the complete image or personality illustrated by e-seller to buyers through writing, style, graphics, colors, logos, slogans, or themes on the website (Srinivasan et al., 2002). In e-commerce sites, managers must design the web creatively to create a positive impression on the minds of buyers and assist e-sellers in creating purchases. E-commerce site designers combine knowledge of design, technology, and social science to design e-commerce sites persuasively, which ideally can increase buyer satisfaction and gradually increase e-seller revenues (Abdul Hamid, Cheun, Abdullah, Ahmad, \& Ngadiman, 2019). Creative websites can create impulse buying (Chen \& Yao, 2018) and become a product attraction and ease of use of the website (Verhagen \& van Dolen, 2011). Zhou, Lu, and Wang (2009) provide information that quality website design can create trust and repurchase. We conclude that e-commerce sites that can be accessed quickly and comfortably can help improve the image of the website and are expected to give the impression of trust to buyers and ultimately can create repeat purchases. Based on the explanation, we hypothesize:

$\mathrm{H} 1$ and $\mathrm{H} 5$ : customization has a positive effect on trust and retention.

$\mathrm{H} 2$ and H6: contact interactivity has a positive effect on trust and retention.

$\mathrm{H} 3$ and $\mathrm{H} 7$ : care has a positive effect on trust and retention.

$\mathrm{H} 4$ and H8: character has a positive effect on trust and retention. 


\section{2. $\quad$ Trust toward Retention}

We already know that forming trust in initial purchases in the context of e-commerce is essential (Qureshi et al., 2009). In the field of information systems science, trust has been studied to understand buyer behavior in e-commerce (Anol, 2002; Ba, Whinston, \& Zhang, 2003; Paul, 2003). They stated that buyer trust is vital for e-sellers to encourage online transactions and form positive attitudes such as repurchase intentions (Bock, Lee, Kuan, \& Kim, 2012; Hong \& Cha, 2013), loyalty (Jun \& XiaoLiang, 2015) and repurchase (Lukito \& Ikhsan, 2020; Xiayu, Qian, Robert, \& Zhongsheng, 2015) so that trust has been assessed as a single object on e-commerce sites and buyers (Xiaolin, Xuequn, \& Nick, 2019; Gilani et al., 2019).

Customer retention is considered customer loyalty (Heskett, Jones, Loveman, Sasser, \& Schlesinger, 1994). Buyer retention places emphasis on e-seller activities in retaining old buyers through the initial trust established by e-sellers. Buyer retention is focused on developing marketing activities that lead to repurchase behavior on managerial aspects of marketers and buyers (Hennig-Thurau \& Klee, 1997). Consumer retention is essential in determining business success, so it is necessary to maintain buyer confidence in the e-commerce context. Forming trust when purchasing early, buyers will be more responsive to buying each type of product, paying more to e-sellers, and creating demand (Cranage, 2004; Peterson, 1995). Dwyer and Tanner (2009) explained that customer retention has a powerful influence on profits. Therefore, e-sellers must have a target to safeguard existing customers and capture new customers who have the potential to bring in profits by the growing trust during initial purchases. Based on the explanation, we hypothesize:

H9: trust has a positive effect on retention.

The results of prior research, we developed a conceptual framework that explains the relationship between variables, as shown below.

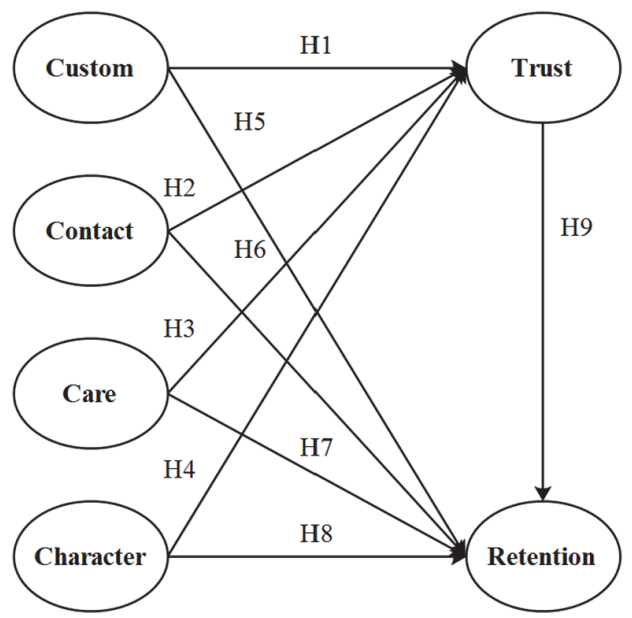

Fig. 1. Conceptual Framework

\section{Methodology}

Measuring the transaction characteristics, we adopt a concept developed by Srinivasan et al. (2002). Measuring trust items, we adopted from Kim and Park (2013) and buyer retention items we adopted from Al-Hawari, Ward, and Newby (2009). To measure all items (see Table 1), we use a five-point Likert scale starting of number 1, which strongly disagrees until number 5 , which is strongly agreed. The population in this study were all buyers from the top six e-commerce sites in Indonesia, namely Blibli, Bukalapak, JD ID, Lazada, Shopee, and Tokopedia. Because the exact population is unknown, we practiced a sample using the Lemeshow method (Lemeshow, Jr, Klar, \& Lwanga, 1990) to obtain a sample size of 384 buyers. The questionnaire was designed with the Google form tool and distributed online by providing a URL through social media. The return rate of the questionnaire was 100 percent. We found 12 percent or 84 invalid responses during the data editing process because they only made purchases on selected e-commerce sites one time in 1 month. The final sample used for analysis is 300. The target sample is those who have made purchases on e-commerce sites at least two times in 1 month, so we call it purposive sampling. The dominant respondents were male (61.3\%). They have an age range of $21-25$ years $(34.7 \%)$. In 1 month, the money spent on online shopping is between Rp.1.000.000 - Rp.1.500.000 (33.7\%). The frequency of shopping on e-commerce sites 6-7 times a month (30\%) and the products most often purchased are fashion (15\%). We use structural equation modeling (SEM) based on Partial Least Square (PLS) with SmarPLS 3.0 software to solve the hypothesis. PLS testing is in two stages (Hair, Hult, Ringle, \& Sarstedt, 2017). First, the measurement model test that is testing validity and reliability. Second, test the structural model to determine whether there is influence between variables or the correlation between variables measured using the t-test. 
Table 1

Measurement Items

\begin{tabular}{|c|c|}
\hline Latent Variable & Item \\
\hline Customization & $\begin{array}{l}\text { a. This e-commerce sites gives product recommendations that fit my needs. } \\
\text { b. This e-commerce sites allows me to order specially made products. } \\
\text { c. Promotions that the website displays have been tailored to my needs. } \\
\text { d. This e-commerce sites makes me a unique customer. } \\
\text { e. I believe this e-commerce site has been adjusted to my needs. }\end{array}$ \\
\hline Contact interactivity & $\begin{array}{l}\text { a. I see products from various angles on e-commerce sites. } \\
\text { b. E-commerce sites have a search feature to find the product that I am looking for. } \\
\text { c. E-commerce sites don't have product comparison features }{ }^{\mathrm{a}} \text {. } \\
\text { d. I feel e-commerce sites very attractive. } \\
\text { e. I believe that e-commerce sites are not dynamic }{ }^{\mathrm{a}} \text {. }\end{array}$ \\
\hline Care & $\begin{array}{l}\text { a. I have encountered problems with billing when purchasing on an e-commerce site }{ }^{\mathrm{a}} \text {. } \\
\text { b. Products that I got from e-commerce sites were delivered on time. } \\
\text { c. I feel that e-commerce sites are slow to respond if I face problems }{ }^{\mathrm{a}} \text {. } \\
\text { d. The product return policy has been set out on the e-commerce site. } \\
\text { e. I understand that e-commerce sites have taken good care of buyers. }\end{array}$ \\
\hline Character & $\begin{array}{l}\text { a. E-commerce site in an attractive design. } \\
\text { b. Shopping on an -commerce site is joy. } \\
\text { c. E-commerce sites do not cause the intention to be visited }{ }^{\mathrm{a}} \text {. } \\
\text { d. I feel happy shopping at e-commerce sites. } \\
\text { e. For me, e-commerce sites don't look attractive }{ }^{\mathrm{a}} \text {. }\end{array}$ \\
\hline Trust & $\begin{array}{l}\text { a. E-commerce sites can be trusted. } \\
\text { b. In mind, I believe that e-commerce sites can protect my interests. } \\
\text { c. I believe this e-commerce site can fulfill its promise. } \\
\text { d. I believe the information provided by e-commerce sites. } \\
\text { e. I believe e-commerce sites make a good impression. }\end{array}$ \\
\hline Retention & $\begin{array}{l}\text { a. I assumed the benefits of e-commerce sites. } \\
\text { b. I recommend the choice of the e-commerce site to others. } \\
\text { c. Confident in the choice of an e-commerce site. } \\
\text { d. Make e-commerce sites the first choice. } \\
\text { e. Switch to another e-commerce when encountering problems. } \\
\text { f. Complain to other buyers. } \\
\text { g. Complain to the administrator of the e-commerce site. } \\
\text { h. Complain to outside participants. } \\
\text { i. I prefer e-commerce sites that offer lower prices. } \\
\text { j. Stay with e-commerce sites even though service costs are increasing. } \\
\text { k. Reducing transactions with e-commerce sites }\end{array}$ \\
\hline
\end{tabular}

Note: bUnfavorable Item

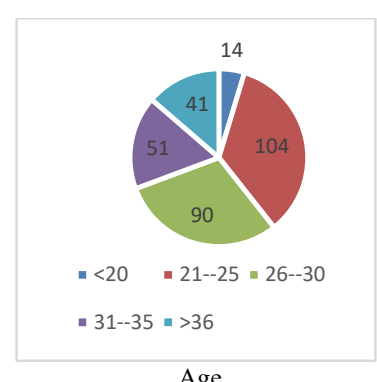

Age

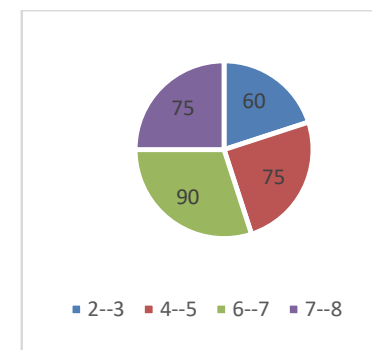

Freq in e-commerce site/ month

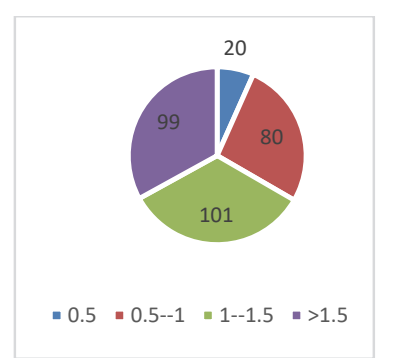

Spending money/ month for shopping $\left(\times 10^{6}\right)$

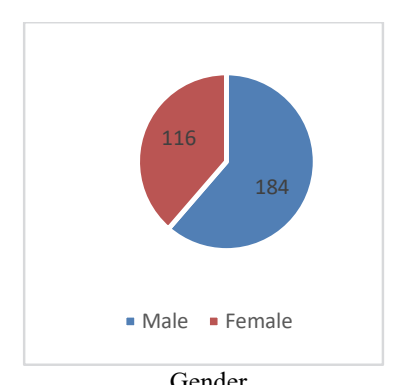

Gender

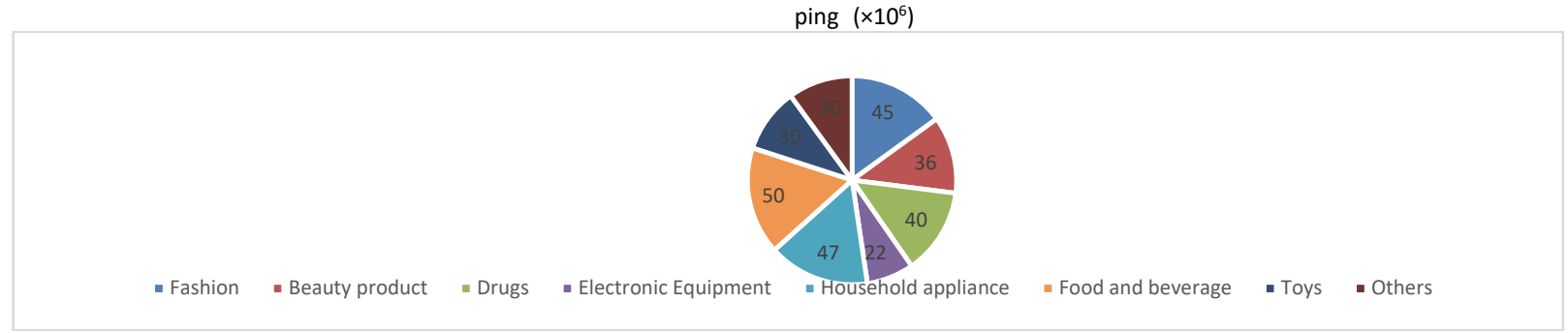

Product purchased

Fig. 2. Demographic characteristics of respondents

The goodness of data testing, we do with the test of convergent validity (loading factor), discriminant validity, average variance extracted (AVE), Cronbach Alpha and Composite Reliability (CR) (Campbell \& Fiske, 1959; Fornell \& Larcker, 1981; Hair, Sarstedt, Hopkins, \& Volker, 2014). The rule of thumb for loading factors of 0.5 and 0.7 has been well-received (Hair et al., 2017). Measurement of discriminant validity with reflective indicators uses the criteria of "cross-loading" (see Table 
4). The recommended discriminant validity value is greater than 0.7 or 0.6 (Garson, 2016). Acceptance of AVE if it has a value greater than 0.5 (Hair et al., 2014). Data consistency has a Composite Reliability (CR) value, and Cronbach's Alpha is greater than 0.7 (Nunnally, 1979). The evaluation of structural models based on R-Square values. R-Square used to measure the accuracy of model predictions. Some researchers suggest the value of R-Square to be at the value of 0.75 (stable), 0.5 (moderate), and 0.25 (weak) (Hair, Ringle, \& Sarstedt, 2011). Cross-validated redundancy $\left(Q^{2}\right)$ testing. $Q^{2}$ value greater than zero shows that the model has an excellent predictive relevance value. They are testing the path coefficients to see the strength of the relationship between variables. Assessing the significance of the path coefficient can be seen from the T-statistics got from the bootstrapping process (resampling method). The significance of the path coefficient can be accepted if the T-statistic value is greater than 1.96 . Finally, we tested the effect sizes for each path model with Cohen's $f^{2}$ guidelines (Hair et al., 2014).

\section{Result}

\subsection{Evaluation of Measurement Models}

The convergent validity testing shows that all indicator on every variable has a loading factor value higher than 0.7 , and only four indicators have a value of 0.6. However, this value is still acceptable in the level of validity success. AVE value in every variable has fulfilled reasonable requirements because it has a value greater than 0.5 . Finally, the value of composite reliability (CR) and Cronbach's alpha has been higher than 0.7, so we conclude that the data used have a good level of consistency to measure each variable. A summary of the results of the goodness of the data test can be seen in Table 2.

Table 2

Convergent validity and Reliability

\begin{tabular}{|c|c|c|c|c|c|}
\hline Laten Variable & Item & Loading Factor & AVE & $\mathrm{CR}$ & Cronbach's Alpha \\
\hline \multirow[t]{5}{*}{ Customization (C) } & $\mathrm{C} 1$ & 0.765 & \multirow{5}{*}{0.687} & \multirow{5}{*}{0.916} & \multirow{5}{*}{0.886} \\
\hline & $\mathrm{C} 2$ & 0.873 & & & \\
\hline & C3 & 0.805 & & & \\
\hline & $\mathrm{C} 4$ & 0.869 & & & \\
\hline & $\mathrm{C} 5$ & 0.827 & & & \\
\hline \multirow{5}{*}{$\begin{array}{l}\text { Contact } \\
\text { (CI) }\end{array}$} & CI1 & 0.780 & \multirow{5}{*}{0.581} & \multirow{5}{*}{0.873} & \multirow{5}{*}{0.817} \\
\hline & $\mathrm{CI} 2$ & 0.772 & & & \\
\hline & $\mathrm{CI} 3$ & 0.830 & & & \\
\hline & CI4 & 0.782 & & & \\
\hline & CI5 & 0.632 & & & \\
\hline \multirow[t]{5}{*}{ Care $(\mathrm{Ca})$} & $\mathrm{Ca} 1$ & 0.715 & \multirow{5}{*}{0.700} & \multirow{5}{*}{0.921} & \multirow{5}{*}{0.891} \\
\hline & $\mathrm{Ca} 2$ & 0.847 & & & \\
\hline & $\mathrm{Ca} 3$ & 0.869 & & & \\
\hline & $\mathrm{Ca} 4$ & 0.875 & & & \\
\hline & $\mathrm{Ca} 5$ & 0.866 & & & \\
\hline \multirow[t]{5}{*}{ Character (Ch) } & Ch1 & 0.854 & \multirow{5}{*}{0.598} & \multirow{5}{*}{0.881} & \multirow{5}{*}{0.831} \\
\hline & $\mathrm{Ch} 2$ & 0.725 & & & \\
\hline & $\mathrm{Ch} 3$ & 0.850 & & & \\
\hline & Ch4 & 0.733 & & & \\
\hline & Ch5 & 0.690 & & & \\
\hline \multirow[t]{5}{*}{ Trust (Tr) } & $\operatorname{Tr} 1$ & 0.823 & \multirow{5}{*}{0.715} & \multirow{5}{*}{0.926} & \multirow{5}{*}{0.900} \\
\hline & $\operatorname{Tr} 2$ & 0.834 & & & \\
\hline & $\operatorname{Tr} 3$ & 0.810 & & & \\
\hline & $\operatorname{Tr} 4$ & 0.888 & & & \\
\hline & $\operatorname{Tr} 5$ & 0.868 & & & \\
\hline \multirow[t]{11}{*}{ Retention (CR) } & CR1 & 0.738 & \multirow{11}{*}{0.512} & \multirow{11}{*}{0.920} & \multirow{11}{*}{0.904} \\
\hline & CR2 & 0.733 & & & \\
\hline & CR3 & 0.709 & & & \\
\hline & CR4 & 0.668 & & & \\
\hline & CR5 & 0.761 & & & \\
\hline & CR6 & 0.718 & & & \\
\hline & CR7 & 0.708 & & & \\
\hline & CR8 & 0.733 & & & \\
\hline & CR9 & 0.672 & & & \\
\hline & CR10 & 0.718 & & & \\
\hline & CR11 & 0.705 & & & \\
\hline
\end{tabular}

Discriminant validity testing shows the items on $\mathrm{C} 1-\mathrm{C} 5, \mathrm{Ca} 1-\mathrm{Ca} 5$, and $\operatorname{Tr} 1-\mathrm{Tr} 5$ have a strong correlation to the variable. Whereas items CI1.CI5, Ch1-Ch5, CR1-CR5 have moderate and robust correlations with the variable. We conclude that all indicators for each variable have good discriminant validity. A summary of the results of the cross-loading test is showing in Table 3. 
Table 3

Discriminant Validity - Cross Loading

\begin{tabular}{|c|c|c|c|c|c|c|}
\hline & Customization & Contact interactivity & Care & Character & Trust & Retention \\
\hline C1 & 0.765 & 0.553 & 0.591 & 0.541 & 0.663 & 0.603 \\
\hline $\mathrm{C} 2$ & 0.873 & 0.426 & 0.670 & 0.498 & 0.587 & 0.684 \\
\hline $\mathbf{C 3}$ & 0.805 & 0.413 & 0.629 & 0.386 & 0.569 & 0.511 \\
\hline $\mathrm{C} 4$ & 0.869 & 0.447 & 0.701 & 0.544 & 0.605 & 0.644 \\
\hline C5 & 0.827 & 0.423 & 0.629 & 0.514 & 0.571 & 0.543 \\
\hline CI1 & 0.445 & 0.780 & 0.475 & 0.457 & 0.562 & 0.553 \\
\hline CI2 & 0.402 & 0.772 & 0.401 & 0.397 & 0.456 & 0.515 \\
\hline CI3 & 0.422 & 0.830 & 0.430 & 0.463 & 0.507 & 0.527 \\
\hline CI4 & 0.425 & 0.782 & 0.386 & 0.434 & 0.445 & 0.443 \\
\hline CI5 & 0.388 & 0.632 & 0.435 & 0.389 & 0.431 & 0.473 \\
\hline Ca1 & 0.514 & 0.360 & 0.715 & 0.431 & 0.542 & 0.491 \\
\hline $\mathrm{Ca} 2$ & 0.652 & 0.420 & 0.847 & 0.569 & 0.610 & 0.597 \\
\hline $\mathrm{Ca3}$ & 0.720 & 0.530 & 0.869 & 0.602 & 0.660 & 0.652 \\
\hline $\mathrm{Ca} 4$ & 0.678 & 0.473 & 0.875 & 0.487 & 0.633 & 0.605 \\
\hline $\mathrm{Ca} 5$ & 0.674 & 0.544 & 0.866 & 0.525 & 0.649 & 0.672 \\
\hline Ch1 & 0.569 & 0.495 & 0.525 & 0.854 & 0.584 & 0.593 \\
\hline Ch2 & 0.361 & 0.385 & 0.376 & 0.725 & 0.485 & 0.413 \\
\hline Ch3 & 0.547 & 0.515 & 0.527 & 0.850 & 0.563 & 0.625 \\
\hline Ch4 & 0.403 & 0.419 & 0.517 & 0.733 & 0.506 & 0.426 \\
\hline Ch5 & 0.417 & 0.339 & 0.479 & 0.690 & 0.466 & 0.364 \\
\hline $\operatorname{Tr} 1$ & 0.588 & 0.568 & 0.628 & 0.571 & 0.823 & 0.605 \\
\hline $\operatorname{Tr} 2$ & 0.650 & 0.617 & 0.660 & 0.655 & 0.834 & 0.674 \\
\hline $\operatorname{Tr} 3$ & 0.528 & 0.488 & 0.498 & 0.527 & 0.810 & 0.541 \\
\hline Tr4 & 0.638 & 0.505 & 0.651 & 0.533 & 0.888 & 0.612 \\
\hline Tr5 & 0.647 & 0.494 & 0.679 & 0.557 & 0.868 & 0.594 \\
\hline CR1 & 0.594 & 0.459 & 0.547 & 0.397 & 0.510 & 0.738 \\
\hline CR2 & 0.531 & 0.463 & 0.562 & 0.420 & 0.549 & 0.733 \\
\hline CR3 & 0.445 & 0.428 & 0.491 & 0.397 & 0.450 & 0.709 \\
\hline CR4 & 0.413 & 0.360 & 0.455 & 0.331 & 0.426 & 0.668 \\
\hline CR5 & 0.538 & 0.547 & 0.545 & 0.493 & 0.620 & 0.761 \\
\hline CR6 & 0.507 & 0.539 & 0.488 & 0.478 & 0.552 & 0.718 \\
\hline CR7 & 0.499 & 0.544 & 0.515 & 0.453 & 0.535 & 0.708 \\
\hline CR8 & 0.590 & 0.547 & 0.549 & 0.506 & 0.555 & 0.733 \\
\hline CR9 & 0.541 & 0.482 & 0.434 & 0.512 & 0.484 & 0.672 \\
\hline CR10 & 0.540 & 0.419 & 0.571 & 0.520 & 0.479 & 0.718 \\
\hline CR11 & 0.471 & 0.389 & 0.538 & 0.501 & 0.461 & 0.705 \\
\hline
\end{tabular}

\subsection{Evaluation of Structural Models}

The structural model represents the relationship between latent variables. The structural model's path coefficients are interpreted as standardized coefficients of OLS (ordinary least square) regression. A summary of the results of structural model calculations is showing in Fig. 3 and Table 4.
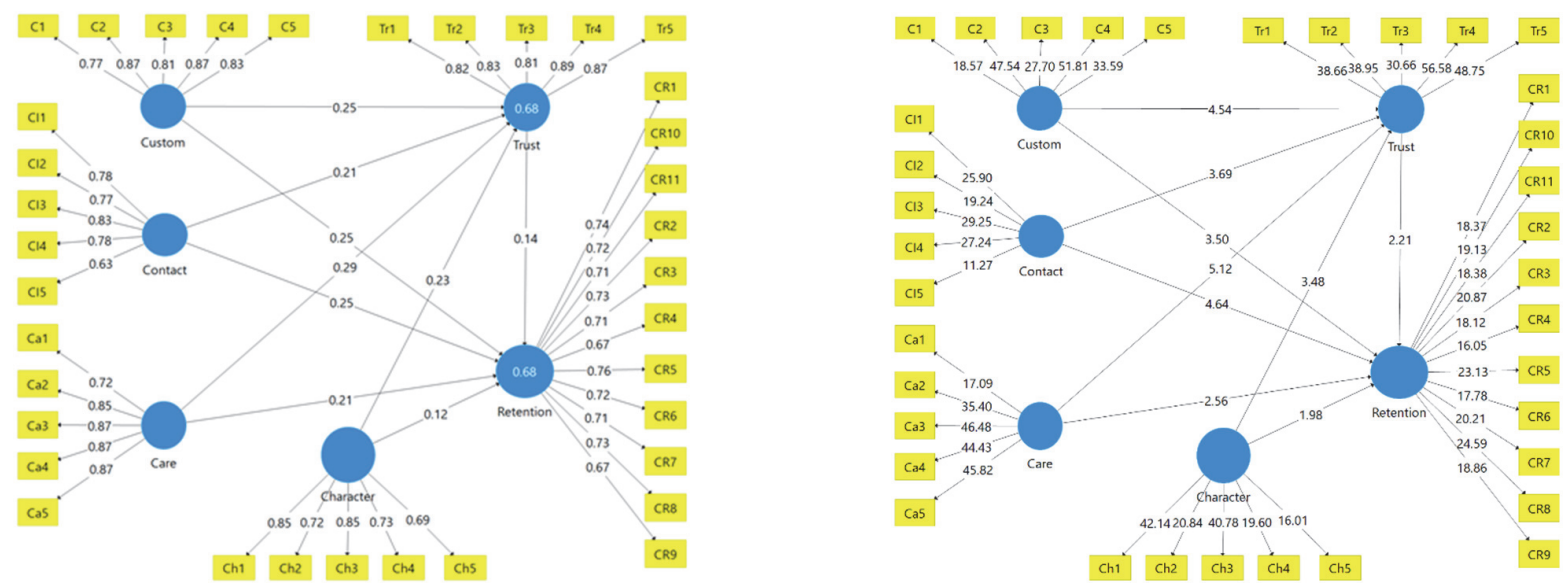

Fig. 3. Structural Model 
Table 4

Hypothesis Testing and $\mathrm{R}^{2}$

\begin{tabular}{clccccc}
\hline Model & \multicolumn{1}{c}{ Path } & Standardized & T-statistics & P-Values & Decision & $\mathrm{R}^{2}$ \\
\hline \multirow{2}{*}{1} & $\mathrm{C} \rightarrow \mathrm{T}$ & 0.25 & 4.543 & 0.000 & H1 Accepted & 0.68 \\
& $\mathrm{CI} \rightarrow \mathrm{T}$ & 0.21 & 3.694 & 0.000 & H2 Accepted & \\
& $\mathrm{Ca} \rightarrow \mathrm{T}$ & 0.29 & 5.116 & 0.000 & H3 Accepted & \\
& $\mathrm{Ch} \rightarrow \mathrm{T}$ & 0.23 & 3.479 & 0.001 & H4 Accepted & 0.68 \\
\hline \multirow{2}{*}{2} & $\mathrm{C} \rightarrow \mathrm{CR}$ & 0.25 & 3.502 & 0.001 & H5 Accepted & H6 Accepted \\
& $\mathrm{CI} \rightarrow \mathrm{CR}$ & 0.25 & 4.642 & 0.000 & 0.011 & H7 Accepted \\
& $\mathrm{Ca} \rightarrow \mathrm{CR}$ & 0.21 & 2.559 & 0.048 & H8 Accepted & \\
& $\mathrm{Ch} \rightarrow \mathrm{CR}$ & 0.12 & 1.985 & 0.027 & H9 Accepted &
\end{tabular}

Proof of acceptance or rejection of the hypothesis refers to the T-statistic or P-value. At the same time, the path coefficient $(\beta)$ shows the direction of the relationship between exogenous and endogenous variables. All of our hypotheses have been proven by testing the structural model and producing two linear equations.

In the first equation, we accept all hypotheses. Customization has a positive and significant effect on trust because it has a Tstatistic value of 4,534 and a P-value of 0,000 with a significance level of 0.05 . The path coefficient $(\beta)$ is positive. There is a linear relationship between customization and trust. Contact interactivity has a positive and significant effect on trust with a T-statistic value of 3,694 and a P-value of 0,000 with a significance level of 0.05 . The path coefficient $(\beta)$ is positive. There is a linear relationship between contact interactivity with trust. Care has a positive and significant effect on trust with a Tstatistic value of 5.116, a P-value of 0.000 with a significance level of 0.05 . The path coefficient $(\beta)$ is positive. There is a linear relationship between care and trust. The character has a positive and significant effect on trust with a T-statistic value of 3,479, a P-value of 0.001 with a significance level of 0.05 . The path coefficient $(\beta)$ is positive. There is a linear relationship between character and trust. The R-Square value in the first equation is 0.68 or $68 \%$. These results signal that transaction characteristics can predict buyer trust in e-commerce sites by $68 \%$ and the equation model in the medium category.

In the second equation, we accept all hypotheses. Customization has a positive and significant effect on buyer retention because it has a T-statistic value of 3,502 and a P-value of 0.001 with a significance level of 0.05 . The path coefficient ( $\beta$ ) is positive. There is a linear relationship between customization and buyer retention. Contact interactivity has a positive and significant effect on buyer retention with a T-statistic value of 4,642 and a P-value of 0,000 with a significance level of 0.05 . The path coefficient $(\beta)$ is positive. There is a linear relationship between contact interactivity with buyer retention. Care has a positive and significant effect on buyer retention with a T-statistic value of 2,559 and a P-value of 0.011 with a significance level of 0.05 . The path coefficient $(\beta)$ is positive. There is a linear relationship between care and buyer retention. A character has a positive and significant effect on buyer retention with a T-statistic value of 1,985 and a P-value of 0.048 with a significance level of 0.05 . The path coefficient $(\beta)$ is positive. There is a linear relationship between character and buyer retention. Trust has a positive and significant effect on buyer retention with a T-statistic value of 2.213 and a P-value of 0.027 with a significance level of 0.05 . The path coefficient $(\beta)$ is positive. There is a linear relationship between trust and buyer retention. The R-Square value in the second equation is 0.68 or $68 \%$. These results signal that transaction characteristics can predict buyer retention on e-commerce sites by $68 \%$ and the equation model in the medium category.

Based on Cohen's $f^{2}$ indicator (see Table 5) variables customization, contact interactivity, care, and character have a small effect on trust, and trust has a small effect on buyer retention behavior on e-commerce sites. Besides, cross-validated redundancy $\left(Q^{2}\right)$ produces a value of 0.898 and is higher than zero so that the model has an excellent predictive relevance value.

\section{Table 5}

The effects between the variables

\begin{tabular}{|c|c|c|c|}
\hline & 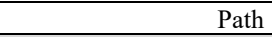 & Cohen's f $^{2}$ & Effect size \\
\hline $\mathrm{C}$ & $\rightarrow \quad \mathrm{T}$ & 0.071 & Small \\
\hline CI & $\rightarrow \quad \mathrm{T}$ & 0.082 & Small \\
\hline $\mathrm{Ca}$ & $\rightarrow \quad \mathrm{T}$ & 0.084 & Small \\
\hline $\mathrm{Ch}$ & $\rightarrow \quad \mathrm{T}$ & 0.089 & Small \\
\hline $\mathrm{C}$ & $\rightarrow \quad \mathrm{CR}$ & 0.065 & Small \\
\hline CI & $\rightarrow \quad \mathrm{CR}$ & 0.108 & Small \\
\hline $\mathrm{Ca}$ & $\rightarrow \quad \mathrm{CR}$ & 0.022 & Small \\
\hline $\mathrm{Ch}$ & $\rightarrow \quad \mathrm{CR}$ & 0.044 & Small \\
\hline $\mathrm{T}$ & $\rightarrow \quad \mathrm{CR}$ & 0.020 & Small \\
\hline
\end{tabular}

Note: $f^{2} 0.02$ (small effects); 0.15 (medium effects); 0.35 (larger effects); less 0.02 zero effects (Cohen, 2013)

Finally, we did not examine the role of trust as a mediating variable. The best reason for not testing the role of mediation in the SEM-PLS model is that there is still some confusion about evaluating the effects of mediation (Hair, Ringle, \& Sarstedt, 2013). An initial illustration on how to analyze the effects of mediation has been done by Hair et al. (2013), but he explained that much research is needed to guide how to evaluate more complex effects such as mediations or mediations. 


\section{Discussion and Conclusions}

This research has specifically discussed the factors that drive buyer retention on e-commerce sites through transaction characteristics (Srinivasan et al., 2002) and buyer confidence. The results of the initial survey found that all indicators of cultivation, community, choice, and convenience proved invalid. The remaining factors are customization, contact interactivity, care, and character. Finally, we learned about these factors. The measurement model illustrates all the indicators we measure are valid and reliable while the structural measurement model, all of the hypotheses we examined, are accepted. Statistically, the accuracy of the prediction models for the first and second equations results in the same R-Square value. We argue that in the first equation, customization, contact interactivity, care, and character factors contribute moderately to buyer's trust in e-commerce sites. In contrast, in the second equation, customization, contact interactivity, care, character, and trust factors contribute to buyer retention on the e-commerce site. We conclude that buyer retention on e-commerce sites can be determined by the characteristics of the transaction and the buyer's trust moderately. Customization factors, contact interactivity, care, and character have a positive and significant effect on buyers' trust and retention. It shows that e-commerce administrators and e-sellers have been able to meet the needs of buyers through customization services. For example, presenting recommendations for goods to be purchased, the availability of pre-order services to make buyers feel that we can meet all their needs. We present the role of contact interactivity on e-commerce sites such as the convenience of buyers finding products through a search menu and an attractive website display to continue to use. Paying attention to buyers in every transaction process and post-purchase becomes an obligation for e-sellers, such as timeliness of delivery of goods, product replacement, and responsiveness to problems that occur. The character of the website is an essential concern for buyers. Creatively designed websites can create a positive impression on the minds of buyers and help e-sellers in creating repeat purchases. Finally, by providing a touch of innovation in the factor of customization, contact interactivity, care, and character can be a competitive advantage to create trust in the initial stages of the purchase and maintain buyer resilience on e-commerce sites.

\section{References}

Abdul Hamid, N. A., Cheun, C. H., Abdullah, N. H., Ahmad, M. F., \& Ngadiman, Y. (2019). Does Persuasive E-commerce Website Influence Users' Acceptance and Online Buying Behaviour? The Findings of the Largest E-commerce Website in Malaysia. In Y. Baghdadi \& A. Harfouche (Eds.), ICT for a Better Life and a Better World: The Impact of Information and Communication Technologies on Organizations and Society (pp. 263-279). Cham: Springer International Publishing.

Al-Hawari, M., Ward, T., \& Newby, L. (2009). The relationship between service quality and retention within the automated and traditional contexts of retail banking. Journal of Service Management, 20(4), 455-472. doi:10.1108/09564230910978539

Alba, J., Lynch, J., Weitz, B., Janiszewski, C., Lutz, R., Sawyer, A., \& Wood, S. (1997). Interactive Home Shopping: Consumer, Retailer, and Manufacturer Incentives to Participate in Electronic Marketplaces. Journal of Marketing, 61(3), 38-53.

Alharbi, H., Ali, \& Alhider, H., Ibrahim. (2018). The Impact of Customer Satisfaction and Loyalty on E-Marketing: Moderating Effect of Perceived Value. Journal of Marketing and Consumer Research, 46, 70-77.

Anol, B. (2002). Individual Trust in Online Firms: Scale Development and Initial Test. Journal of Management Information Systems, 19(1), 211-241.

Ba, S., Whinston, A. B., \& Zhang, H. (2003). Building trust in online auction markets through an economic incentive mechanism. Decision Support Systems, 35(3), 273-286.

Berthon, P., Pitt, L., \& Watson, R. (1996). The WWW as an advertising medium: Toward an understanding of conversion efficiency. Journal of Advertising Research, 36(1), 43-54.

Bitner, M. J., Booms, B. H., \& Tetreault, M. S. (1990). The Service Encounter: Diagnosing Favorable and Unfavorable Incidents. Journal of Marketing, 54(1), 71-84.

Bloemer, J., de Ruyter, K., \& Wetzels, M. (1999). Linking perceived service quality and service loyalty: a multi-dimensional perspective. European Journal of Marketing, 33(11/12), 1082-1106. doi:10.1108/03090569910292285

Bock, G.-W., Lee, J., Kuan, H.-H., \& Kim, J.-H. (2012). The progression of online trust in the multi-channel retailer context and the role of product uncertainty. Decision Support Systems, 53(1), 97-107. doi:https://doi.org/10.1016/j.dss.2011.12.007

Boulding, W., Kalra, A., Staelin, R., \& Zeithaml, V. A. (1993). A dynamic process model of service quality: From expectations to behavioral intentions. Journal of Marketing Research, 30(1), 7-27. doi:10.1177/002224379303000102

Campbell, D. T., \& Fiske, D. W. (1959). Convergent and discriminant validation by the multitrait-multimethod matrix. Psychological Bulletin, 56(2), 81-105. doi:10.1037/h0046016

Chen, C.-C., \& Yao, J.-Y. (2018). What drives impulse buying behaviors in a mobile auction? The perspective of the StimulusOrganism-Response model. Telematics and Informatics, 35(5), 1249-1262. doi:https://doi.org/10.1016/j.tele.2018.02.007

Coelho Pedro, S., \& Henseler, J. (2012). Creating customer loyalty through service customization. European Journal of Marketing, 46(3/4), 331-356. doi:10.1108/03090561211202503

Cohen, J. (2013). Statistical Power Analysis for the Behavioral Sciences (Revised ed.). New York: Academic Press.

Cranage, D. (2004). Plan to do it right: and plan for recovery. International Journal of Contemporary Hospitality Management, 16(4), 210-219. doi:10.1108/09596110410537360

Culnan, M. J., \& Armstrong, P. K. (1999). Information privacy concerns, procedural fairness, and impersonal trust: An empirical investigation. Organization Science, 10(1), 104-115. doi:10.1287/orsc.10.1.104

Cuneo, A. Z. (1995). Internet world show spurs online commerce debate. Advertising Age, 17, 16. 
Das, S., Mishra, A., \& Cyr, D. (2019). Opportunity gone in a flash: Measurement of e-commerce service failure and justice with recovery as a source of e-loyalty. Decision Support Systems, 125, 113130. doi:https://doi.org/10.1016/j.dss.2019.113130

Deighton, J., \& Sorrell, M. (1996). The future of interactive marketing. Harvard business review, 74(6), 151-160.

Dirks, K. T., \& Ferrin, D. L. (2001). The role of trust in organizational settings. Organization Science, 12(4), $450-467$.

Doan, T. (2020). Factors affecting online purchase intention: A study of Vietnam online customers. Management Science Letters, $10(10), 2337-2342$.

Dwyer, F. R., \& Tanner, J. F. (2009). Business marketing: Connecting strategy, Relationships, and Learning: McGraw-Hill Irwin.

Fornell, C., \& Larcker, D. F. (1981). Structural equation models with unobservable variables and measurement error: Algebra and statistics. Journal of Marketing Research, 18(3), 382-388. doi:10.1177/002224378101800313

Garson, D. R. (2016). Partial Lease Squares: Regression \& Structural Equation Models USA: Statistical Publishing Associates.

Grabner-Kraeuter, S. (2002). The role of consumers' trust in online-shopping. Journal of Business Ethics, 39(1), 43-50.

Gilani, E., Salimi, D., Jouyandeh, M., Tavasoli, K., \& Wong, W. (2019). A trend study on the impact of social media in decision making. International Journal of Data and Network Science, 3(3), 201-222.

Ha, L., \& James, E. L. (1998). Interactivity reexamined: A baseline analysis of early business web sites. Journal of Broadcasting \& Electronic Media, 42(4), 457-474. doi:10.1080/08838159809364462

Hair, J. F., Hult, G. T. M., Ringle, C., \& Sarstedt, M. (2017). A Primer on Partial Least Squares Structural Equation Modeling (PLS-SEM) (Second ed.). United States of America: SAGE Publications.

Hair, J. F., Ringle, C. M., \& Sarstedt, M. (2011). PLS-SEM: Indeed a Silver Bullet. Journal of Marketing Theory and Practice, 19(2), 139-152. doi:10.2753/MTP1069-6679190202

Hair, J. F., Ringle, C. M., \& Sarstedt, M. (2013). Partial least squares structural equation modeling: Rigorous applications, better results and higher acceptance. Long range planning, 46(1-2), 1-12.

Hair, J. F., Sarstedt, M., Hopkins, L., \& Volker, G. K. (2014). Partial least squares structural equation modeling (PLS-SEM): An emerging tool in business research. European Business Review, 26(2), 106-121. doi:10.1108/EBR-10-2013-0128

Hennig-Thurau, T., \& Klee, A. (1997). The impact of customer satisfaction and relationship quality on customer retention: A critical reassessment and model development. Psychology \& Marketing, 14(8), 737-764. doi:10.1002/(sici)15206793(199712)14:8<737::Aid-mar2>3.0.Co;2-f

Heskett, J. L., Jones, T. O., Loveman, G. W., Sasser, W. E., \& Schlesinger, L. A. (1994). Putting the service-profit chain to work. Harvard business review, 72(2), 164-174.

Hoffman, D. L., Novak, T. P., \& Peralta, M. (1999). Building consumer trust online. Communications of the ACM, 42(4), 80-85.

Hong, I. B., \& Cha, H. S. (2013). The mediating role of consumer trust in an online merchant in predicting purchase intention. International Journal of Information Management, 33(6), 927-939. doi:https://doi.org/10.1016/j.ijinfomgt.2013.08.007

Hoque, A. S. M. M. (2018). The effect of entrepreneurial orientation on Bangladeshi SME performance: Role of organizational culture. International Journal of Data and Network Science, 2(1), 1-14.

Jain Nikunj, K. (2017). E-fulfillment dimensions and its influence on customers in e-tailing: a critical review. Asia Pacific Journal of Marketing and Logistics, 29(2), 347-369. doi:10.1108/APJML-11-2015-0167

Jaiswal, A. K., Niraj, R., Park, C. H., \& Agarwal, M. K. (2018). The effect of relationship and transactional characteristics on customer retention in emerging online markets. Journal of Business Research, 92, 25-35.

Jun, C., \& Xiao-Liang, S. (2015). Consumers' decisions in social commerce context: An empirical investigation. Decision Support Systems, 79, 55-64.

Kim, S., \& Park, H. (2013). Effects of various characteristics of social commerce (s-commerce) on consumers' trust and trust performance. International Journal of Information Management, 33(2), 318-332.

Lee, J., Lee, Y., \& Lee, Y.-J. (2012). Do customization programs of e-commerce companies lead to better relationship with consumers? Electronic Commerce Research and Applications, 11(3), 262-274.

Lee, J., Park, D. H., \& Han, I. (2011). The different effects of online consumer reviews on consumers' purchase intentions depending on trust in online shopping malls: An advertising perspective. Internet Research, 21(2), 187-206.

Lemeshow, S., Jr, D. W. H., Klar, J., \& Lwanga, S. K. (1990). Adequacy of Sample Size in Health Studies. England: John Wiley \& Sons.

Li, Y.-M., \& Yeh, Y.-S. (2010). Increasing trust in mobile commerce through design aesthetics. Computers in Human Behavior, 26(4), 673-684.

Lin, J., Wang, B., Wang, N., \& Lu, Y. (2014). Understanding the evolution of consumer trust in mobile commerce: a longitudinal study. Information Technology and Management, 15(1), 37-49. doi:10.1007/s10799-013-0172-y

Lukito, S., \& Ikhsan, R. (2020). Repurchase intention in e-commerce merchants: Practical evidence from college students. Management Science Letters, 10(13), 3089-3096.

Maxwell, S., \& Khan, A. M. (2018). Electronic Customer Relationship Management (E-CRM): A Study of Its Role, Influence \& Benefitsto E-Commerce. Management Dynamics, 18(1), 43-51.

Mohapatra, S. (2013). E-Commerce Strategy. In S. Mohapatra (Ed.), E-Commerce Strategy: Text and Cases (pp. 155-171). Boston, MA: Springer US.

Nili, A., Barros, A., Johnstone, D., \& Tate, M. (2019). Technological enablers for preventing service failure with e-commerce websites. In R. Helms, P. Agerfalk, \& P. Johannesson (Eds.), Proceedings of the 27th European Conference on Information Systems (pp. 1-14). https://aisel.aisnet.org/: Association for Information Systems.

Nunnally, J. C. (1979). Psychometric theory. New York: McGraw-Hill Education. 
Oliver, R. L. (1999). Whence consumer loyalty? Journal of Marketing, 63(4_suppl1), 33-44.

Otim, S., \& Grover, V. (2006). An empirical study on Web-based services and customer loyalty. European Journal of Information Systems, 15(6), 527-541.

Paul, A. P. (2003). Consumer acceptance of electronic commerce: Integrating trust and risk with the technology acceptance model. International Journal of Electronic Commerce, 7(3), 101-134.

Peterson, R. A. (1995). Relationship marketing and the consumer. Journal of the Academy of Marketing Science, 23(4), $278-281$.

Qureshi, I., Fang, Y., Ramsey, E., McCole, P., Ibbotson, P., \& Compeau, D. (2009). Understanding online customer repurchasing intention and the mediating role of trust - an empirical investigation in two developed countries. European Journal of Information Systems, 18(3), 205-222.

Reichheld, F. F., \& Sasser, W. E. (1990). Zero defeofions: Quoliiy comes to services. Harvard business review, 68(5), $105-111$.

Salimon, M., Mokthar, S., Yusr, M., Yusoff, R., Kareem, O., \& Bamgbade, J. (2018). Do risk and fun matter in the adoption of mobile commerce in Nigeria? A PLS-SEM approach. Management Science Letters, 8(6), 507-518.

Sarkar, S., Chauhan, S., \& Khare, A. (2020). A meta-analysis of antecedents and consequences of trust in mobile commerce. International Journal of Information Management, 50, 286-301.

Srinivasan, S. S., Anderson, R., \& Ponnavolu, K. (2002). Customer loyalty in e-commerce: an exploration of its antecedents and consequences. Journal of Retailing, 78(1), 41-50.

Susanti, K., Prijono, T., Rizal Edy, H., \& Asnan, F. (2019). Informational justice and post-recovery satisfaction in e-commerce: The role of service failure severity on behavioral intentions. The Journal of Asian Finance, Economics and Business, 6(1), 129-139.

Verhagen, T., \& van Dolen, W. (2011). The influence of online store beliefs on consumer online impulse buying: A model and empirical application. Information \& Management, 48(8), 320-327.

Watson, R. T., Akselsen, S., \& Pitt, L. F. (1998). Attractors: Building mountains in the flat landscape of the world wide web. California Management Review, 40(2), 36-56. doi:10.2307/41165932

Williamson, O. E. (1993). Calculativeness, trust, and economic organization. The Journal of Law and Economics, 36(1, Part 2), 453-486. doi:10.1086/467284

Xiaolin, L., Xuequn, W., \& Nick, H. (2019). Building e-commerce satisfaction and boosting sales: The role of social commerce trust and its antecedents. International Journal of Electronic Commerce, 23(3), 328-363.

Xiayu, C., Qian, H., Robert, D., \& Zhongsheng, H. (2015). What drives trust transfer? The moderating roles of seller-specific and general institutional mechanisms. International Journal of Electronic Commerce, 20(2), 261-289.

Zaheer, A., McEvily, B., \& Perrone, V. (1998). Does trust matter? Exploring the effects of interorganizational and interpersonal trust on performance. Organization Science, 9(2), 141-159. doi:10.1287/orsc.9.2.141

Zhou, T., Lu, Y., \& Wang, B. (2009). The relative importance of website design quality and service quality in determining consumers' online repurchase behavior. Information Systems Management, 26(4), 327-337.

Zo, H. (2003). Personalization vs. Customization: Which Is More Effective in E-Services? Paper presented at the AMCIS 2003 Proceedings.

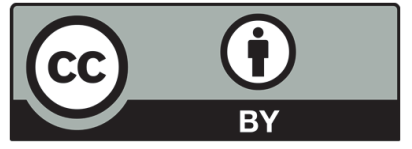

(C) 2020 by the authors; licensee Growing Science, Canada. This is an open access article distributed under the terms and conditions of the Creative Commons Attribution (CC-BY) license (http://creativecommons.org/licenses/by/4.0/). 